\section{Å leve med multippel sklerose}

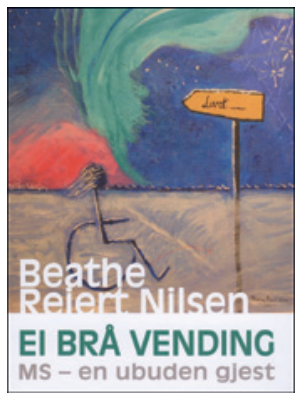

\section{Beathe Reiert Nilsen.}

Ei brå vending

MS - en ubuden gjest. $151 \mathrm{~s}$, ill. Bodø: Licentia Forlag, 2011. Pris NOK 299

ISBN 978-82-8258-043-4

Beathe Reiert Nilsen er samfunnsviter, klinisk sosionom og kunstterapeut. I over 20 år arbeidet hun i helse- og sosialomsorgen, inntil hun fikk primær progressiv multippel sklerose (PPMS). Ei brå vending er en personlig beretning om det å få en slik sykdom i voksen alder og å lære seg å leve med den. Boken er skrevet i en folkelig og muntlig form, nesten som en dagbok. Likevel kan den til tider være noe tung å lese på grunn av layouten. Den kontinuerlige teksten har få avsnitt. Det er tre deler. Forfatteren har brukt maling som egenterapi, og har selv laget illustrasjonene.

Formålet er å gi et innblikk i hvordan det er å leve med denne typen multippel sklerose. Omtrent $15-20 \%$ av pasientene debuterer med dette sykdomsforløpet. Primær progressiv multippel sklerose karakteriseres ved jevn progredierende uførhet, og behandlingen er kun symptomatisk. Lite oppmerksomhet er blitt viet denne gruppen, og forfatteren bidrar derfor til å sette søkelyset på dette sykdomsforløpet.

I første del beskriver hun det snikende sykdomsforløpet med diffuse symptomer over flere år, og den lange veien til en endelig diagnostisk avklaring. Etter å ha jobbet innenfor helsevesenet selv skildrer forfatteren møtet med helsevesenet som pasient. I løpet av $11 / 2$ år var hun i kontakt med over 30 ulike leger. Det er ikke bare de vanlige symptomene som utmattelse (fatigue), smerte, gang- og balansevansker som beskrives detaljert, men også mer tabubelagte områder som vannlatings- og avføringsproblemer samt kognitiv svikt.

Forfatteren beskriver ikke bare sorgen over det gradvise tapet av fysiske funksjoner, men også konsekvensene dette har: ikke lenger å mestre dagligdagse ting som sosiale aktiviteter og bilkjøring, det økende behovet for hjelpemidler og ikke minst forholdet til familie og arbeid.

I andre del skisserer forfatteren ulike mestringsstrategier som har fungert for henne, og som også kan komme andre til gode. Dette gir også håp om at det er mulig å leve et verdig og meningsfylt liv til tross for alvorlig kronisk sykdom.

Ordliste med fagord og forklaringer, liste over litteraturhenvisninger og oversikt over nettsteder inngår i tredje del, og de kan være nyttige.

Nilsen belyser de mange ulike og komplekse aspektene ved multippel sklerose, inkludert eksistensielle problemstillinger. Jeg anbefaler boken til målgruppene: pasienter med multippel sklerose, pårørende og hjelpepersonell. Den vil kunne bidra til økt forståelse for, og innsikt $i$, en alvorlig sykdom som primært rammer unge voksne, og som er en av de vanligste årsakene til invaliditet $\mathrm{i}$ denne aldersgruppen.

\section{Solveig B. Glad}

Nevrologisk avdeling

Haukeland universitetssykehus

\section{Mye godt om utviklingshemning}

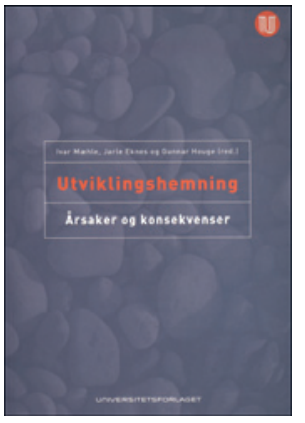

Ivar R. Mæhle, Jarle Eknes, Gunnar Houge, red.

Årsaker og konsekvenser. 270 s, tab, ill. Oslo: Universitetsforlaget, 2011. Pris NOK 359 ISBN 978-82-15-01300-8

Redaktørenes ambisjon er å dele kunnskap med fagfolk og foreldre. De angir selv gode grunner for hvorfor de har valgt tema som de har gjort. Boken er oversiktlig bygd opp med seks seksjoner med underkapitler. Referanselisten synes passe fyldig, og både innholdsfortegnelse og stikkordregister gjør det lett å finne frem.

Forfatterne og deres bakgrunn er kort omtalt. Teksten er illustrert med figurer, tabeller og bilder på en utmerket måte. I noen kapitler er det egne rammer med nøkkelinformasjon som fungerer godt, og noen kapitler har skyggelagte felt med fiktive kasuistikker som illustrerer budskapet med innlevelse. Faguttrykk er forklart i varierende grad. De fleste kapitlene avsluttes med henvisning til ressurser på nett. De jeg kjenner til, er gode, og forfatterne har heldigvis ikke begrenset seg til skandinaviske nettsteder. Første kapittel, skrevet av moren til en funksjonshemmet jente (Ingen er perfekt!), og siste seksjon, skrevet av fagfolk (Tre historier om å leve med en diagnose som innbcrer psykisk utviklingshemning), rammer det øvrige innholdet fint inn.

Første seksjon heter Innledende og overordnede tema. Hensikten er, ifølge forfatteren, å øke forståelsen av hva som kan gå galt i utviklingsprosesser. Grunnleggende genetiske prinsipper blir forklart, satt i en epidemiologisk sammenheng og knyttet til gjengse feiloppfatninger.

Fosterdiagnostikk av genetisk sykdom og syndromutredning behandles i egne kapitler. Her vil jeg tro at alle typer lesere får svar på viktige spørsmål. Men - og dette er en hovedinnvending leserne fortjener i tillegg et innledende kapittel om den diagnostiske prosessen ved kognitive utviklingsavvik -

og en avklaring av terminologien i de følgende kapitlene.

Andre og tredje seksjon omhandler genomiske og genetiske tilstander. Til sammen behandler forfatterne 38 navngitte syndromer. De genetiske prinsippene er gjennomgående godt forklart. Personlig tror jeg de lengre avsnittene om de mer velkjente syndromene, hvor atferdstrekk og medisinsk oppfølging også blir gjennomgått, har mest å tilføre sammenliknet med andre informasjonskilder.

Fjerde seksjon handler om miljøfaktorer, hvor føtalt alkoholsyndrom er viet størst plass. Femte seksjon om tilleggsvansker har relevante og gode kapitler om cerebral parese, epilepsi og autisme.

Vi trenger en slik bok på norsk - og denne er skrevet av fremragende fagfolk. Genetikken er grundig behandlet og satt i en større sammenheng. Andre utgave kan bli virkelig god.

Kjersti Ramstad

Barneavdeling for nevrofag

Oslo universitetssykehus, Rikshospitalet 